\title{
6
}

\section{Money Trees, Development Dreams and Colonial Legacies in Contemporary Pasifika Horticultural Labour}

\author{
Victoria Stead
}

Rosemary and I are sitting at a round plastic table, out the front of the small cabin she shares with four other Ni-Vanuatu women in a caravan park in north-central Victoria. It is about six o'clock in the evening and they, and another $14 \mathrm{Ni}$-Vanuatu living in the surrounding cabins, have not long gotten back from their shifts sorting and packing boxes of apples and pears at a local packing shed. As we sit drinking mugs of tea, some of the older women inside the cabin are preparing dinner in a small, portable convection oven perched on a bench in the cramped kitchen space. Outside, others are making their way to or from the shower block at the other end of the caravan park, carrying with them the work clothes that they wash daily in the showers to save the two dollars required to use the park's washing machines. Rows of work clothes, imprinted with the logo of the packing shed where the group work, hang from clothes lines strung up between the caravans. The group arrived four months ago as part of the Seasonal Worker Programme (SWP) that brings Pacific Islander workers to labour in the Australian horticultural industry on a seasonal basis; they will be here for another two months before they return to Vanuatu. This is Rosemary's third trip, and she will return again in subsequent years if she is able. Her experience at the packing shed has been positive by many measures; however, other $\mathrm{Ni}$-Vanuatu workers have 
had negative experiences and, in any case, even those aspects she finds positive are never quite straightforwardly so. We drink our tea slowly and our conversation turns to the experiences of another group of Ni-Vanuatu workers, mostly male, who are also resident at the same caravan park and working picking tomatoes on a nearby farm. It has been a poor season for tomatoes and, with the men paid on a piece rate basis, the poor size and quality of the crop makes for tough work and very low pay. Rosemary is narrating a conversation she had with another Pacific Islander, not a temporary labour migrant but a resident in the area. In discussing the workers' conditions, particularly on the tomato farm, the man had said to her, 'you know what, this is what we call modern-day slavery'. I mention the allusion to the nineteenth-century blackbirding of Melanesians, many of them Ni-Vanuatu, to the sugar cane plantations of Queensland and northern New South Wales. Rosemary pauses, sips her tea, and replies: 'Yes, that was us'.

Pacific Islanders have long formed a significant component of the workforce within Australian horticulture (fruit and vegetable production). The labours of contemporary Pacific Islanders who travel to rural Australia as temporary workers, as well as the labours of settled Pacific Islanders who form a significant part of the workforce in many rural areas, take place within complex ecologies and histories of colonial encounter. Most notably, the contemporary horticultural labour of Pacific Islanders takes place against the historical backdrop of the nineteenthcentury Pacific labour trade, which saw thousands of Pacific Islanders 'blackbirded'-transported through coercion, kidnapping or trickeryfrom their Melanesian homes, or else recruited in legal but nevertheless exploitative conditions, to labour on the cane fields of north-eastern Australia. ${ }^{1}$ This is a period of Australian and Pacific history that has been written about powerfully by Tracey Banivanua Mar and others. ${ }^{2}$ It is invoked by contemporary Australian South Sea Islander activists, who are the descendants of those blackbirded workers and who are campaigning for recognition of the Pacific labour trade and the harms done to their ancestors. It is also a history that is sometimes invoked by contemporary Pacific Islanders in response to their own labour experiences, or those of their kin or community. These references to the blackbirding past

1 Connell, 'From Blackbirds to Guestworkers'.

2 Banivanua Mar, Violence and Colonial Dialogue; Banivanua Mar, Decolonisation and the Pacific. See also, Munro, 'The Pacific Islands Labour Trade'; Saunders, 'Masters and Servants'; Graves, Cane and Labour. 
are often made to draw parallels between historical and contemporary labour experiences, and often invoke the language of 'slavery' in doing so. This language appears in descriptions of Pacific Islander workerspast and present-as 'slaves', as well as through references to the 'slavelike' conditions of some contemporary Pacific Islander labour, and in descriptions of contemporary Pacific Islander labour migrations, as in the vignette above, as 'modern-day slavery'. These references, and invocations of the past, have also found expression in a stream of news reports about exploitation in the scheme and the industry more widely, including reports commenting on concerns raised within the context of the Australian Government's parliamentary inquiry into modern slavery, and local arenas such as the 2017 community forum on modern slavery held at Mildura in northern Victoria. ${ }^{3}$ At the same time, though, some contemporary Pacific Islander workers also describe the fruit trees they labour on as 'money trees', and large numbers of Pacific Islanders, like Rosemary, desire and actively seek out opportunities for horticultural work in rural Australia, including through the SWP, which is actively promoted (and often pursued) as a path to 'development'. ${ }^{4}$

'Money trees', development dreams and colonial legacies thus converge, and sometimes collide, in the orchards, caravan parks, churches and community spaces of rural Australia. In this chapter, I explore the complex, charged discourses and affects that accompany these convergences, focusing particularly on the experiences of Pacific Islanders who prune, thin and harvest the fruit trees of the Greater Shepparton Region in north-central Victoria. Placing contemporary Pasifika labour in conversation with its historical antecedents, I map out some of the key contours of debates among historians about the nature of the nineteenth-century labour trade, and the proper relationship between recognising Pacific Islander agency and the coercive force of the state and labour recruiters. I also engage with more contemporary discussions about 'modern-day slavery', race and

3 For example, Emma Field, 'Seasonal Worker Program Exploitation Claims Raised at Mildura Forum', Weekly Times, 31 October 2017, www.weeklytimesnow.com.au/news/national/seasonalworker-program-exploitation-claims-raised-at-mildura-forum/news-story/6e49e03051905d7204f bb35753e0bd64; Locke, Buchanan and Graue, 'Seasonal Worker Program'; Ben Doherty, 'Hungry, Poor, Exploited: Alarm over Australia's Import of Farm Workers', The Guardian, 3 August 2017, www. theguardian.com/global-development/2017/aug/03/hungry-poor-exploited-alarm-over-australiasimport-of-farm-workers; Nick McKenzie, 'Slavery Claims as Seasonal Workers from Vanuatu Paid Nothing for Months' Work', The Sydney Morning Herald, 27 March 2017, www.smh.com.au/national/ slavery-claims-as-seasonal-workers-from-vanuatu-paid-nothing-for-months-work-20170327-gv7k99. $\mathrm{html}$. On the Australian Government's parliamentary inquiry, see Joint Standing Committee on Foreign Affairs, Hidden in Plain Sight, particularly Chapter 9.

4 Doyle and Sharma, 'Maximizing the Development Impacts from Temporary Migration'. 
migration. However, in doing so, I am not so much interested in wading into debates about whether or not Pacific horticultural labour is or was 'slavery' as I am in charting some of the different ways in which slavery has been imagined and discursively mobilised. For all the scholarly merit of debates around whether the Pacific labour trade constituted slavery, ${ }^{5}$ the danger in these debates is that they slip into a particular mode of legalistic technicality, and of contestation around terminology and definitional criteria, that can miss the lived substance and experience of what people are talking about when they invoke the language of slavery. Likewise, with debates over the definitional scope and parameters of 'contemporary' or 'modern slavery'. ${ }^{6}$ What I seek to do in the following pages, then, is to interrogate discourses both of 'slavery' and of 'development' as two intersecting strands of narrative and meaning-making that circulate in relation to Pacific Islander horticultural labour, and through which contemporary Pacific Islanders locate themselves in relation to contested colonial pasts. These discourses articulate with one another in the messy terrain of everyday encounter and affect and, in doing so, tell us something about the kinds of precarity experienced by Pacific Islander horticultural workers, the continuities and colonial legacies that inform contemporary Pacific Islander lives, and the interplays of structural forces and Pasifika agency.

\section{Blackbirds, Slaves and Willing Workers}

From 1863 until Federation in 1901, some 60,000 men, women and children were transported to the cane fields in north-eastern Australia from what are now the countries of the Solomon Islands, Vanuatu, Papua New Guinea, Fiji and Kanaky/New Caledonia. Debates about how best to characterise and understand the migrations of these Pacific Islanders have occupied historians over the last 60 or so years, hinging particularly on the question of the relationship between coercion and agency. There is broad agreement that the early years of the trade, particularly, were characterised by incidences of coercion, trickery, deceit and, sometimes, outright kidnapping of workers by recruiters - those practices captured in

5 For example, Graves, Cane and Labour; Munro, 'Revisionism and Its Enemies'; Munro, 'The Pacific Islands Labour Trade'; Scarr, 'Recruits and Recruiters'; Shlomowitz, 'Markets for Indentured'; Shlomowitz, 'Time Expired Melanesian Labor in Queensland'.

6 For example, Weitzer, 'Human Trafficking and Contemporary Slavery'; Quirk, 'The Anti-Slavery Project'. 
the descriptor 'blackbirding. ${ }^{7}$ Commencing after the abolition of slavery in Britain in 1833, blackbirding was never formally part of the slave trade, and commentators have disagreed, often vehemently, over the extent to which it might be compared to, or indeed classified as, slavery. Indeed, as Reid Mortensen has shown in his analysis of trials in Australian courts of recruiters charged with abuses in this early period, the question of whether the labour trade constituted slavery was very much alive at the time of the trade itself, with attempts made in $1869-71$ to use post-abolition anti-slavery legislation as a basis for prosecution. Ultimately, while some recruiters were found guilty of kidnapping, the effect of the cases was to draw a legal distinction between that offence and slavery proper. ${ }^{8}$ The cases nevertheless draw attention to the definitional debates and subjective, contested uses to which both 'slavery', and the murky descriptor 'slaverylike', have been and continue to be put.

By the mid-1870s, the Pacific labour scheme was largely regulated, and outright forcible recruitment had largely given way to at least nominally voluntary enlistment, mediated through the legal mechanism of indenture. It was this shift, in particular, that was highlighted in a body of revisionist scholarship, commencing in the late 1960s, that aimed to draw attention to the agency and active, consensual participation of Pacific Islanders within the labour trade. As Deryck Scarr put it in an early and influential voluntarist account, the Pacific labour trade was, from the mid-1870s, a 'business' - brutal and sometimes backed up by force, to be sure, but a business nonetheless, and one that operated with the consent of those involved. ${ }^{9}$ Other revisionists emphasised the role of Pacific Islander agents and facilitators of the trade, with Clive Moore, for example, re-evaluating the role of 'beach payments' given by recruiters to the relatives of Malaitans recruited from Solomon Islands, not as payments indicative of human purchase (and thus of slavery) but rather as gifts in the spirit of reciprocal relations. ${ }^{10}$ Others pointed to the high prevalence of so-called 'time-expired' workers, namely those who signed up for a second period of service after their initial period of indenture was completed, as evidence of the voluntary nature of the trade. ${ }^{11}$

7 Banivanua Mar, Violence and Colonial Dialogue; Munro, 'The Pacific Islands Labour Trade'; Shlomowitz, 'Markets for Indentured'; Shlomowitz, 'Time Expired Melanesian Labor'.

8 Mortensen, 'Slaving in Australian Courts'.

9 Scarr, Fragments of Empire, 139. See also Scarr, 'Recruits and Recruiters'.

10 Moore, Kanaka: A History of Melanesian Mackay.

11 For example, Shlomowitz, 'Markets for Indentured'; Shlomowitz, 'Time Expired Melanesian Labor in Queensland'. 


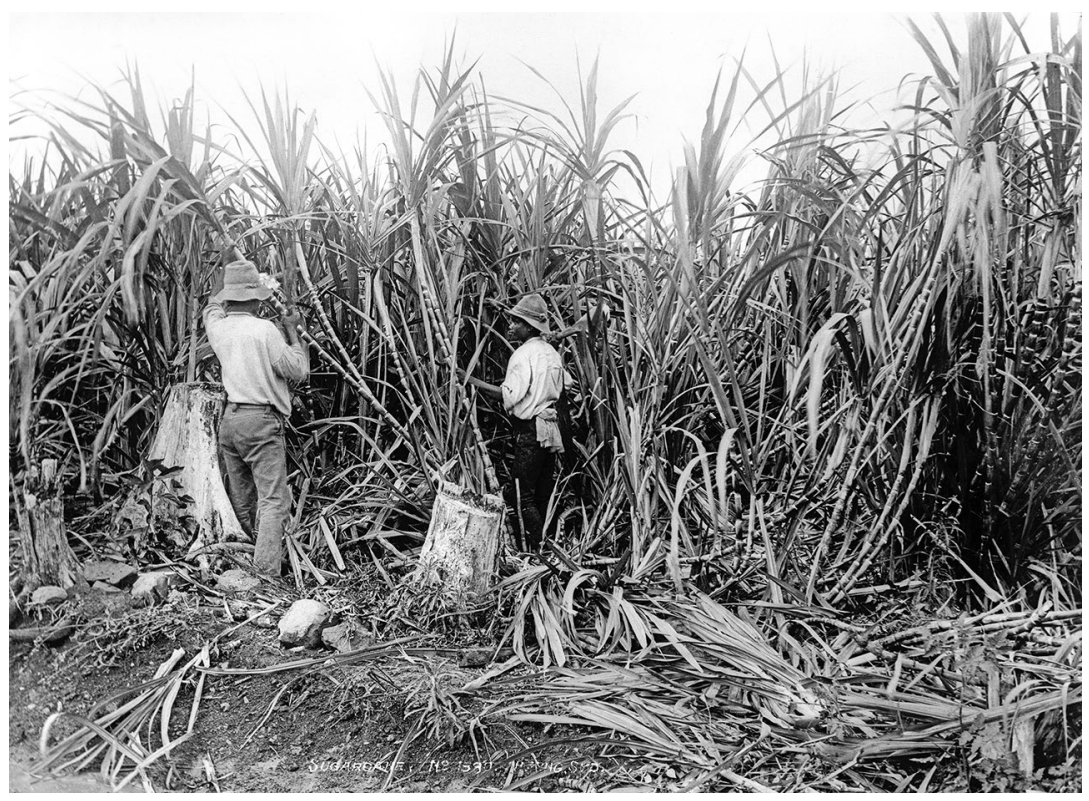

Figure 6.1: South Sea Islanders on a Queensland sugar plantation at the end of the nineteenth century.

Source: Photograph by Henry King, 'Sugarcane', c. 1880-1900, Museum of Applied Arts \& Sciences, Object 85/1285-1138, accessed 14 March 2019, ma.as/30615.

In emphasising the voluntary nature of participation, the revisionists were, in part, motivated by the push towards 'island-oriented' histories being championed through the late 1960s into the early 1990s, particularly within The Australian National University. To this extent, they were interested in highlighting the agency of Pacific Islanders, both in their recruitment and in their control over their own working lives. The rush to credit agency, though, often came at a cost of minimising the coercive conditions within which (and against which) agency was enacted; these are not always neatly counter-posed forces. As Tracey Banivanua Mar argued in her groundbreaking book, Violence and Colonial Dialogue:

For all the exercise of agency on the part of Islanders, the labor trade was not, as many have written, a benign labor migration. It was a trade in labor. Searching for signs of historical agency should not preclude the ongoing recognition that the labor trade was premised on a determination to be profitable, which ultimately rendered negligible (unless profitable) the existence of agency. In other words, and in relation to current debates over the appropriateness of slavery as a description for the labor trade, 
resistance or agency take their meaning from the oppressive context against which they are asserted. In the end, surely some measure of the 'damage' inflicted can derive from the number of times we feel we must assert that people were resisting agents. ${ }^{12}$

In place of a zero-sum consideration of Islander agency and colonial force, Banivanua Mar called instead for attention to the 'dialogue' between the 'vertical' structures of colonial power and communication, and the 'horizontal' rhythms of Islanders' own exchanges, decisions, actions and interrelations. This approach-also evident in her chapter in this volume-is one in which 'Islanders' agency, resistance, and consciousness can be celebrated, but not at the expense of minimizing scrutiny to the violent capabilities of colonization'. ${ }^{13}$ It is an approach, as well, that acknowledges and holds space for the multiple modalities of violence through which colonialism was conceived, enacted, reasoned and rationalised in the labour frontiers of the Pacific Islands as well as on the plantations of north-eastern Australia. Colonial violence, Banivanua Mar showed, was physical, discursive and economic, and bound up in racialised stereotypes that legitimated gross inequalities and mistreatment. It was also, often, a 'regulated standard', wielded through systematised and legal standards of indenture, accommodation, diet and care that resulted in sometimes extraordinarily high mortality rates, as well as through extra-legal modalities of brute force and terror. ${ }^{14}$ This 'regulated standard' has echoes in the restrictive and racialised nature of regulation in the labour migrations of Papuan and New Guinean domestics, some 50 to 70 years later, described by Lucy Davies in this volume.

The bifurcation of coercion and voluntarism both echoes and emerges out of the positioning of 'slavery' and 'freedom' as counter-posed values within the structures of Enlightenment thought. ${ }^{15}$ It is a bifurcation that struggles to accommodate the lived complexities of power and agency, whether they be within the context of the formal slave trade, nineteenthcentury indenture, or indeed the increasingly broad and amorphous range of labour relations that are included within a growing scholarship on so-called 'new' or 'modern slavery'. ${ }^{16}$ Encompassing wage exploitation,

12 Banivanua Mar, Violence and Colonial Dialogue, 12.

13 Banivanua Mar, Violence and Colonial Dialogue, 7.

14 Banivanua Mar, Violence and Colonial Dialogue, 13.

15 Davidson, 'Troubling Freedom'.

16 On 'modern slavery' see, for example, Weitzer, 'Human Trafficking and Contemporary Slavery';

Quirk, 'The Anti-Slavery Project'; Bales, Disposable People. 
involuntary servitude, debt bondage, human trafficking, forced marriage and other 'slavery-like' conditions as diverse as honour killings, genital mutilation, child soldiers and the sale of organs, scholarly and policy treatments of modern slavery are spectacularly broad, inherently subjective and often political. ${ }^{17}$ Many of the types of labour relations that fall under the banner of modern slavery are elsewhere captured by the descriptor of 'unfree labour', a phrase that has, in recent years, been used to describe various guestworker schemes, as well as a host of other conditions that fall uncomfortably outside the counter-posed extremes of coercion and voluntarism. ${ }^{18}$

Focusing on contemporary debt-financed migration as particularly 'troubling' of the forced/voluntary dyad, Julia O'Connell Davidson argues that migrants may well voluntarily enter debt relationships that entail severe restrictions on their freedom, both because they are enacting agency in contexts of limited or unequal choice, and also because their migration is oriented towards temporal, as well as spatial, horizons. That is to say, we need to consider the future-oriented aspirations that can compel migrants to accept present conditions, even unfree or exploitative ones, as well as the past experiences or conditions that inform their decision-making.

In highlighting the constrained conditions within which choice is exercised by contemporary debt-financed migrants, Davidson echoes points made in relation to the nineteenth-century Pacific labour trade. For example, Adrian Graves argued that Pacific Islanders often signed up to the trade because of a lack of alternatives in the face of drought and capitalist disruption of local economies. ${ }^{19}$ Doug Munro has subsequently raised questions about Graves' argument, pointing out that extensive outmigration often occurred in places where there had been less penetration by European capitalism; however, he nevertheless concurs with the need to consider the options and alternatives available. 'Melanesians', Munro writes, 'often recruited only in the absence of better alternative means to obtaining European goods' ${ }^{20}$ Similarly, Moore argues that there was little recruiting from areas beyond the 'labour frontier' in Solomon Islands, where communities already had access to Western goods from traders,

17 Altman, 'Modern Slavery in Remote Australia?'; Bales, Disposable People; Davidson, 'Troubling Freedom'; Weitzer; Quirk, 'The Anti-Slavery Project'.

18 Basok, 'Free to Be Unfree'; Miles, Capitalism and Unfree Labour; Lewis et al., 'Hyper-Precarious Lives'.

19 Graves, 'The Nature and Origins of Pacific Islands Labour'.

20 Munro, 'Revisionism and Its Enemies: Debating the Queensland Labour Trade', 242. 
and the option of cash cropping as an alternate pathway to development. ${ }^{21}$ Attending to the temporal horizons of people's choices, as well to the cultural and imaginative dimensions through which coercion was (and is) produced, we also need to ask why European goods were so sought after, and how it was that developmentalism's future orientations were produced through colonial encounters. This is to attend both historically and anthropologically to the intersection of coloniality and Pasifika agency.

Doing so calls attention to race as a structure of power underpinning the collisions of development dreams, agency and colonial force on the beachfront labour frontiers of the nineteenth century as well as in the orchards and packing sheds where contemporary Ni-Vanuatu labour. To draw on the late Patrick Wolfe, practices of racialisation are the means through which groups of colonised peoples have been (and continue to be) marked, coopted into unequal relationships, governed and assigned their place within colonial orders. ${ }^{22}$ The violence of the nineteenth labour trade was made possible, as Banivanua Mar documented, by racialised stereotypes of savagery that produced Melanesians as 'colonizable, oppressable, and exploitable'..$^{23}$ Agricultural labour in tropical northeastern Australia was popularly understood as fatal to white workers, but 'constitutionally suited' to the 'lower races'. ${ }^{24}$ It was also understood as having civilising benefits. As the lawyer defending the recruiter John Coath, charged with kidnapping nine men from Vanuatu's Epi Island, declared in 1871: 'It is no offence to go to islands inhabited by a savage and barbarous people, and to bring these people into the protection of English law. ${ }^{\prime 25}$ In fact, the use of indenture as a mechanism for organising Pacific labour involved a substantial reconfiguration of race and plantation labour. Globally, prior to abolition, indentured servitude had been primarily used for securing white labour, sourced from temperate Europe for the similarly temperate plantations of the Caribbean and the Americas, in contrast to the non-white labour mobilised through the slave trade for tropical or semitropical plantation economies. In the wake of slavery's abolition, white servitude gradually gave way to voluntary forms of labour migration, while servitude, through indenture, was recast as the mechanism through which to organise non-white labour. Indenture

21 Moore, Kanaka: A History of Melanesian Mackay.

22 Wolfe, Traces of History.

23 Banivanua Mar, Violence and Colonial Dialogue, 3.

24 Saunders, 'Masters and Servants', 98.

25 Quoted in Mortensen, 'Slaving in Australian Courts'. 
became, then, 'a racial category as well as a legal formula'. ${ }^{26}$ It was this racialisation that made indenture, as Hugh Tinker put it in relation to the indenture of Indian workers, 'a new system of slavery', differing only in that it was temporary rather than permanent bondage. ${ }^{27}$ This racialisation was critical to the lived experience and enactment of indenture. Further, as Ann Curthoys and Clive Moore argue in their historiographic essay on Aboriginal and Torres Strait Islander labour, this racialisation has made 'ex-slave status' an intrinsic part of the self-understanding and historical consciousness of Aboriginal peoples and Melanesians alike.

\section{Work and Place in North-Central Victoria}

In Shepparton, the horticultural work that Ni-Vanuatu workers do today is predominantly seasonal labour, which is to say labour that is tied to particular stages of production and harvest-fruit picking, pruning, thinning — and that generally involves working on farms owned by others. This work is done on the pear and apple orchards that cover large sections of the landscape, on the other fruit and vegetable farms that make up a secondary part of the local industry, and in the packing sheds where fruit is sorted for quality and packaged prior to transportation to supermarkets or to the local SPC Ardmona cannery. Seasonal labour is usually paid on a piece rate basis, although the Ni-Vanuatu workers in the packing shed received a much-desired hourly rate, and packing shed work is often available on a year-round basis, thanks to developments in refrigeration technologies that allow fruit to be stored for long periods of time after its harvest.

In packing sheds and on farms, Ni-Vanuatu labour alongside other Pacific Islanders-particularly Tongans and Samoans-from a small but growing local Pacific Islander population that has been resident in the region for about 30 years, with many of its members now permanent residents or citizens. They also work alongside recently arrived refugees from Afghanistan and the Horn of Africa, as well as Chinese, Malaysian, Albanian and other migrants, both settled and temporary. Additional to these are the large numbers of, predominantly European, backpackers who travel to the region to work for periods of 88 days as a pathway to

26 Munro, 'The Pacific Islands Labour Trade', 89.

27 Tinker, A New System of Slavery. 
receiving a second year-long extension of their Working Holiday Maker visas. Dominant narratives in the region-including those of council and local business groups - celebrate its cultural diversity and history of migration, although these narratives also belie experiences of racism and marginalisation among migrants, as well as among the region's Indigenous people, the Yorta Yorta. ${ }^{28}$ The extensive role of Yorta Yorta labour in the early years of the industry's formation is largely obscured within popular accounts of the region's history. Meanwhile, pervasive narratives that 'locals don't do fruit picking work anymore' leave unrecognised the work of the many local workers, including resident Pacific Islanders and asylum seekers, who do make up a significant section of the industry's workforce. These narratives function to code 'local' as 'white' in ways that discursively and epistemically exclude others from belonging.

The establishment of the fruit-growing industry in the region dates back to the mid-1800s, beginning with the arrival in the area of white settlers in 1838. These were followed by squatters who 'opened up' huge tracts of land and, later, surveyors who parcelled it up for sale to 'men of means' in the 1850s-70s. This was, of course, a process of colonial settlement and Indigenous dispossession. Seasonal labour in the early years of the industry was done by settlers and Yorta Yorta. From the early twentieth century through to the 1980s, it was largely done by itinerant male workers known as canecutters. These men, usually European and single, would migrate on an annual labour circuit, beginning in the cane fields of Queensland and northern New South Wales, moving down to pick apples and pears in north-central Victoria, and then up towards Robinvale and Mildura in the state's north-west. Pacific Islander labour was never used within the north-central Victorian area during the period of the Pacific labour trade, but blackbirding was certainly implicated in the wider patterns of labour and race relations that affected the area. The labour circuits of canecutters, in particular, followed from an economic restructuring of the Queensland sugar industry following the cessation of the labour trade in the early twentieth century.

This restructuring, which was accompanied by the deportation of many Melanesians back to the Pacific, required a shift from the use of indentured Pacific Islander labour towards the use of white labour. The 'bitterly fought' debates that accompanied this transition reveal 
themes that continue to animate contemporary debates over the SWP. The shift required a change in the racialised narratives that had positioned agricultural labour as precisely unsuited to such workers who, at any rate (it was argued), would have been degraded by the experience of doing "'niggers" work'. ${ }^{29}$ This was a reconfiguring that nevertheless continued to invoke starkly racialised hierarchies. Thus, a growing union presence in the Queensland sugar industry began to campaign against the use of 'Kanaka' labour on the basis that it denied employment to white Australians and posed a threat to community safety and moral integrity. Asserting the superiority of white workers, union campaigns demanded that they receive superior conditions to those of non-white workers, and argued vehemently when they did not. Kay Saunders quotes from an article in the union newspaper The Worker in 1911, which angrily decried the treatment of a group of white mill workers who had been housed in the same accommodation previously used for indentured Melanesian workers, and who were 'herded together, without privacy or convenience and with the smell of the kanakas in their nostrils all the time'. ${ }^{30}$

This was the context in which the canecutters emerged as a prominent source of plantation labour, and subsequently of harvest labour, in the south-east horticultural regions. They remained the key source of harvest labour in the Victorian industry until around the 1980s, when the numbers of canecutters began to decline as socio-economic shifts encouraged a reduction in this kind of domestic itinerant labour. In Shepparton, the shift away from canecutters also reflected shifts in the local industry, including a decline in the proportion of fruit being sold for the canneries, and a concomitant increase in the proportion being produced for the fresh fruit market. With this came a shift away from 'strip-picking' - in which all the crop on a tree is removed in one gotowards forms of selective picking on the basis of size, colour and quality, and a lower tolerance for bruising or damage to the fruit (which are less consequential when fruit is being peeled and preserved in the canning process). Farmers in the region describe the unsuitability of the 'rough' and 'tough' canecutters to this more selective form of harvesting.

29 Saunders, 'Masters and Servants', 99.

30 Saunders, 'Masters and Servants', 100. 
In lieu of canecutters, farmers turned increasingly to backpacker labour, with the introduction of the first working holiday visa in 1975, available in the first instance to young people from the United Kingdom and Canada, but subsequently expanded between 1980 and 2006 to include other countries. Since 2005, young people on one-year Working Holiday Maker visas (subclasses 462 and 417) have had the option of securing a second year-long visa upon completion of 88 days of 'specified work' in a rural industry, most commonly fruit picking. Backpackers have thus become a significant component of harvest workforces, but the industry has continued to experience difficulties in securing what it considers adequately reliable and sufficiently plentiful labour. At the same time, Pacific Island countries have long lobbied for temporary labour access for Pacific Islander workers. The push from Pacific Island countries, lobbying from the Australian Farmers Federation and the success of New Zealand's seasonal worker scheme for Pacific workers (the Recognised Seasonal Employer scheme) were among the factors that led to the introduction of the Pacific Seasonal Worker Pilot Scheme in 2009, with the SWP proper commencing in 2012. ${ }^{31}$ Nationally, including in Shepparton, the take up of the SWP was slower than initially anticipated, but is growing. Pacific Islander workers are promoted to farmers (through labour hire company and government marketing) as well-suited to horticultural labour (not unlike their nineteenth-century forebears). While the administrative and bureaucratic requirements of recruiting workers through the SWP are off-putting for many farmers, what appeals about the scheme is that the workers' mobility (and thus agency) is controllable in ways that the mobility of backpackers is not. Whereas backpackers can, and do, leave or change employers if conditions are poor, the visa conditions that tie SWP workers to specific employers mean that they lack that critical negotiating chip. For employers, this is a key benefit of the scheme. As one of the managers of the packing shed put it, describing their decision to use workers through the SWP, 'we can get a group of staff and know that they can't actually go and work anywhere else'. In key ways, what the scheme represents is a new form of indenture.

31 MacDermott and Opeskin, 'Regulating Pacific Seasonal Labour in Australia'; Maclellan and Mares, 'Remittances and Labour Mobility in the Pacific'; Mares and Maclellan, 'Pacific Seasonal Workers for Australian Horticulture'. 


\section{Discourses of Slavery Today}

The Ni-Vanuatu workers assigned to the packing shed arrived in Australia with two other groups of $\mathrm{Ni}$-Vanuatu whose migration and recruitment was managed by the same labour hire agency. The packing shed workers and the group assigned to the tomato farm - those whose labour conditions prompted the allusion to 'modern-day slavery'-stayed at the same caravan park in one of the region's small towns. The third group, assigned to pick apples and pears, were accommodated on the orchard of the farmer for whom they worked. While the packing shed workers were predominantly female, ranging in age from early 20 s to mid-50s, the other two groups were primarily male (as, indeed, most SWP workers have been).

The seasonal nature of horticultural work makes it, by its nature, precarious-farmers often need to pull together workforces at short notice, and dissolve them again just as quickly. Unexpected weather events and a host of other factors can have sudden and dramatic effects on the availability of work. The payment of piece rates (e.g. per bin of fruit picked) enables the flexibility that farmers seek, and is also widely understood (by farmers) to motivate workers to work faster. However, the variability of horticultural production means that piece rates can also be highly variable. This is what played out with the group of $\mathrm{Ni}$-Vanuatu workers allocated to the tomato farm. Like other SWP workers, the group had guaranteed minimum hours; however, the crop at the tomato farm had been particularly poor that season. Small tomatoes, and fewer fruit on plants, meant that it took longer and was harder work to fill the bins, and, with piece rates, fewer bins equated to lower pay. This was coupled with regular deductions from workers' pay, which are a major source of grievance for many SWP workers, including those working at the packing shed who were otherwise pleased to enjoy hourly rates. SWP workers have their accommodation, transport, mandatory health insurance (because they are not entitled to public health care) and other aspects of their living conditions while in Australia organised for them by their employers or by the labour hire companies managing their employment. This is packaged as part of the pastoral care dimension of the scheme-bound up in its developmentalism-but also functions as a control on the movement of workers, amid a context of Australian governmental anxiety about Pacific workers 'absconding' and overstaying their visas. Thus, expenses are set outside of the control of workers themselves, with deductions taken from their pay to cover their repayment. Many workers must also make repayments to cover part of the cost of their travel to and from Australia, and the effect of all of these deductions, when 
coupled with low pay from piece work, is that workers, like the Ni-Vanuatu picking on the tomato farm, can be left making little more than a pittance. Crucially, whereas backpackers who found themselves picking a poor-sized and poor-quality crop could — and generally would-leave in search of better conditions, SWP workers do not have this option available to them. As Makiko Nishitani and Helen Lee explain in this volume, this is a critical factor in the preference of many of their informants in the north-west Victorian region of Mildura to work informally rather than through the SWP. It is this constrained mobility, and the experience of it as racialised and unequal (in relation to other groups of workers), that fuels discourses of slavery.

Beyond the packing sheds, caravan parks, orchards and community spaces of Australia's horticultural regions, these discourses also, increasingly, circulate via social media networks that extend transnationally across Australia and the Pacific, and provide important forums for sharing stories and experiences about the SWP, as well as about New Zealand's equivalent Recognised Seasonal Employer (RSE) scheme, and life more generally across the Pasifika diaspora. In July 2017, a post on the popular Facebook group Café Koko Samoa prompted an extensive discussion, garnering thousands of comments over a period of a few months. The post that launched this particular discussion featured a short exposéstyle video about Pacific Islanders reportedly being paid $\$ 9$ or less a week while working on a South Australian farm, because of the kinds of factors described above related to piece rate pay and deductions. Among the pages of comments, slavery was a persistent theme, invoked in ways that explicitly referenced the labour trade and blackbirding past. For example:

'Get out of [there]. We aint slaves. Fuck tht [sic] shit.'

'modern day slavery'

'this is slave labour'

'Slave labor. wake up Australia'

'We are People of the Pacific that had a lot of respect towards any other human race when they come to our land of pride but saddly [sic] that we are treated like slaves because of our colour or our way of living.'

'Racism and modern day slavery'

'Blackbirders'

'This is slavery'

'Hey look out! ... I thought slave days were long gone.' 
References to slavery were intertwined with a wider discussion of colonial histories and colonial continuities across the region. At one point, the discussion deviated into a debate between Samoans and Māori about whether New Zealand or England was responsible for Samoa's colonisation. Other commenters invoked Australia's settler colonial history and its treatment of Aboriginal people. Still others picked up on the South African accent of the farmer featured in the expose, with one declaring: '[he] thinks he's got black African slaves like back in his country!' Some United Statesbased Pasifika drew in references to the mistreatment of Mexican workers, and to the enslavement and indenture of African Americans. Another commented, in response to the sprawling and wideranging discussion: 'We calling out ALL colonizers.' Thus situated, slavery was produced as a referent that invoked specific pasts, such as the blackbirding of Pacific Islanders to Australia, as well as much wider complexes of race, inequality and exploitation extending across both the past and the present. It became a powerful motif through which people's affective responses to those specific and generalised structures of power-anger, outrage, sadnesscould be articulated.

\section{Development Dreams}

Yet, even as discourses of slavery proliferate-as one commentator on the Café Koko Samoa post put it, 'these stories just keep coming'Pacific Islander participation in the SWP continues to be actively sought. Pacific Island countries lobbied hard for labour mobility schemes to Australia and continue to advocate for their expansion. Within the 10 participating countries, there are high levels of demand for SWP places. Like many of the trans-Tasman migrants described by Ruth Faleolo in this volume, Pacific Islanders seeking access to the scheme pursue Australia as a 'land of milk and honey'-a land considered to offer possibilities not attainable in the islands or in New Zealand. However, unlike trans-Tasman migrants, those seeking places in the SWP do not enjoy freedom of entry into Australia and face onerous migration and labour regimes. In Shepparton, the group of Ni-Vanuatu workers-all of whom had willingly, often enthusiastically, pursued employment through the SWP-had negotiated long and complex processes to secure their places. These processes required prospective migrants finding agents back in Vanuatu that would put their names forward, and leveraging personal connections to ensure that their inclusion on various lists translated into 
actual possibilities for work. The packing shed workers had then needed police and medical clearances and to pass selection tests and interviews conducted in Port Vila by representatives of the packing house company before their positions were finally confirmed.

Many of the packing shed workers pointed to positive aspects of their labour migration experiences. As one woman put it: 'We are lucky, so lucky to come.' Grace, one of the workers on her third SWP placement in Australia, used the income from her first year to purchase a large freezer and a portable ice box and establish a small business with her husband, buying fish from their home island that they freeze, transport to the Vanuatu capital, Port Vila, and sell for a profit in the urban market. She used her earnings from the second year to purchase a car that she runs as an informal transport business. Anne, another of the returning workers, described her joy the year before when, mid-way through her placement, she heard from her husband that the money she had been sending back had finally paid off the loan that they had taken out to purchase land and a house in Port Vila, on the country's largest island Efate:

I feel excited and tears running down my face, my cheeks because I, like, never expected ... So that's why I am come here from three years now ... I've got two things that I came here for: the school fees for my children and my land.

Several other women were similarly hoping to use the money they earned to purchase land for a house in Vila or elsewhere on Efate. As Rachel Smith notes in relation to Ni-Vanuatu participating in the New Zealand RSE scheme, 'the affective value of place (ples) is crucial to social identity' within Vanuatu, and the attainment of a 'good house' has become a key indicator of the moral and material achievement through overseas horticultural work. ${ }^{32}$ Others among the group of packing shed workers were paying school fees for their children; several were also using their income and their location in Australia to purchase cooking equipment that they intended to use for informal entrepreneurial activity back in Vanuatu, or mobile phone handsets, bluetooth speakers and other goods that they hoped to be able to resell for a profit. Many of the women also valued their trip as an 'experience' or an 'adventure'. All said they would like to return again in following seasons.

32 Smith, 'Changing Standards of Living', 45. 


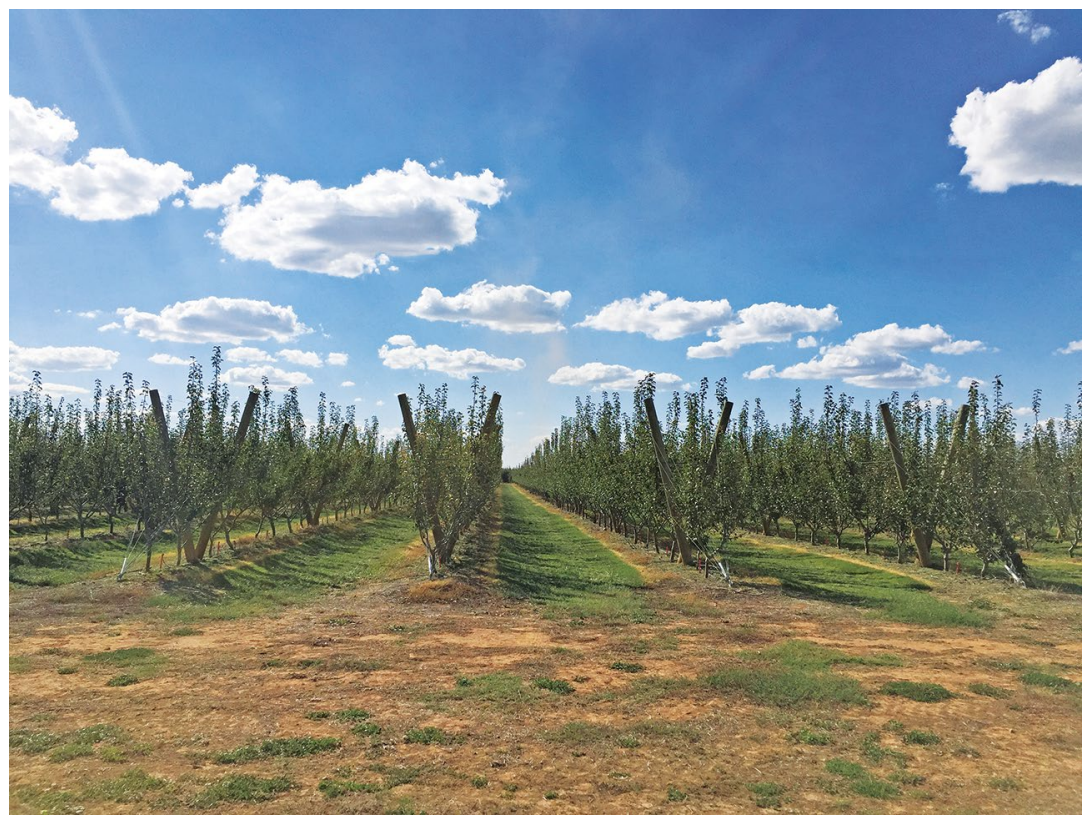

Figure 6.2: Money trees.

Source: Photograph by Victoria Stead.

The development dreams that coalesce around horticultural labour also extend to Pacific Islander communities that are permanently resident in Shepparton. At the start of a recent harvest season, Sina, a Samoan woman whose family has been resident in the region for over 30 years, posted a photo of rows of apple trees on her social media account. She captioned the photo: 'Been a long time-getting that $\$ \$ \$$ for Christmas. Can always count on the trees to give when in need lol. \#oldschoolskills \#moneytrees.' Her friend commented in reply: 'Money does grow on trees.' Indeed, horticultural work is a large part of what has drawn Pacific Islanders to the region. It remains a primary occupation for much of the local Pasifika community, and most of those resident in the region-including Sina's own family-also commit time and resources to facilitating and supporting the migrations, both temporary and permanent, of their kin in New Zealand, Samoa and Tonga, who also want to come and work on the money trees. 


\section{Work and Dreams Beyond the Forced/Free Dyad}

How do we make sense of these tensions and competing narratives about Pacific Islander horticultural labour? One explanation, of course, is simply that different Pacific Islander workers have different experiences. Some have a positive time and experience benefits, others have a negative time and experience exploitation. Certainly, Pacific Islanders working in the horticultural industry today are not a homogeneous or undifferentiated group. For example, the Ni-Vanuatu women working in the packing shed had, on the whole, a much more favourable experience than the workers at the tomato farm. As an explanatory framework, though, this fails to account for the intersections of different imaginaries-of development dreams and blackbirding legacies—or for the ambivalences and multiplicities of Pacific Islander experiences of horticultural work, both past and present.

Writing in a blog post for a development policy website, the economist Stephen Howes highlighted findings from a 2015 survey, conducted by the World Bank, of close to 400 Pacific seasonal workers. The survey found that 98 per cent would refer the SWP scheme to a friend, and that workers, on average, rated their satisfaction with the scheme at 8.6 out of 10. Howes, having long opposed media reports making the link between contemporary seasonal labour and slavery, concluded triumphantly:

Overwhelmingly, seasonal workers have a great time here in Australia; they want their friends to come and work here; and they are returning themselves for more of the same. It is nothing like blackbirding. ${ }^{33}$

There are a number of questions that could be asked of the World Bank survey's methodology, not least related to the intense anxieties that many SWP workers-including those in Shepparton-feel about the possibility of any negative feedback by them about the scheme getting back to employers who have the power to determine whether or not they are able to come back in subsequent years. More fundamentally, the question that needs to be asked is about the capacity for statistics like 98 per cent, or 8.6 out of 10 , to tell a full and human story of Pacific Islanders' experiences of horticultural labour. 
Thus, Sina, my Samoan friend in Shepparton who describes the fruit trees her family picks, prunes and thins as 'money trees', also narrates her father's three decades of horticultural labour in the region through reference to his aching back, chronic respiratory problems and a gruelling weight of obligation to kin back in Samoa who cannot secure Australian visas. She describes her frustration with the persistent lack of recognition of the contributions her father and other Pasifika workers in Shepparton make to the industry. She recounts how the farmer for whom her father and uncle have worked, for years, enthusiastically welcomes back each season the white workers who travel down from Queensland for harvest, sidelining her father and uncle who work day in, day out, keeping the farm ticking over.

Grace and Anne, two of the Ni-Vanuatu women who highlighted positive aspects of their work, also describe the work as 'difficult' and 'hard'. They talk about being hyper-scrutinised by farmers who stand behind them as they work the line at the packing shed, watching how they pack the fruit, correcting them and pushing them to work faster. They describe feeling unappreciated, and they struggle with not knowing from year to year whether they will be invited back again. They talk about being beholden to labour hire agents who mediate their employment and wield enormous power, often unscrupulously. They recount with sadness their isolation in the tiny rural town where they are accommodated, and their almost complete lack of interaction with local residents there.

Mary, who, in her early 20s, is one of the younger women in the group of packing shed workers, is also planning to use the money she earns through the SWP to buy land to build a house in Port Vila. She estimates that she can earn four times in Australia what she can back home. She, like the others, and like the survey respondents Howes invokes, would readily come back in subsequent years. However, she is also a single mother, and has had to leave her seven-year-old son behind with extended family while she is here for six months. She aches for him, as do others in the group who have left behind young children. One night, while sharing a meal in the caravan park where the workers stay, one of the male Ni-Vanuatu workers assigned to the tomato farm asks me, gently, if he can pick up and cuddle my then two-year-old son who is there with me. He tells me he is the same age as his twins, and as he sits with my son snuggled on his lap he shows me their picture on his phone. He has not seen them in five months. 
These ambivalences find little expression in the World Bank's ' 98 per cent' and ' 8.6 out of 10 ' ratings. Nor, and this is perhaps the more significant point, do these figures capture the structural, racialised and historical conditions that inform both the contemporary conditions and experiences of seasonal labour, and the choices that SWP workers are able to make. When Mary leaves behind her son to work in the SWP so she can make money to build a home for the two of them, she does so in large part because foreign demand for beachside land in Efate has massively increased land pressures for $\mathrm{Ni}-\mathrm{Vanuatu}$, and made land all but unattainable for Ni-Vanuatu working for local wages. ${ }^{34}$ This foreign demand for land includes demand by Australians keen for their own piece of tropical Vanuatu 'paradise'. Not unlike the choices of Pacific Islanders who voluntarily boarded the ships of nineteenth-century recruiters, the choices that contemporary Ni-Vanuatu make are made in contexts in which their alternatives are limited (and structurally so), and in which forces of race and coloniality serve to position particular forms of life and goods as valuable and desirable. As post-development critics and anthropologists of development have argued forcefully, 'development' is at once ideological, material and affective; it acts on the subjectivities of those who are deemed in need of it, and is experienced in ways that can be at once profound and deeply ambivalent. ${ }^{35}$

Thus, when local Samoan and Tongan workers experience their own labour being devalued and unrecognised, they do so in the context of long-running, known and felt histories of racialised inequalities that render particular types of people and bodies as 'constitutionally suited' for tough, agricultural labour, and simultaneously diminish their contributions. These are the structural conditions within which both development dreams and discourses of modern-day slavery are entangled with one another and made meaningful. Participation in the SWP can thus be sought after, valued, even enjoyed in part, and also be experienced as reflective, and indeed constitutive, of deeply entrenched inequalities that run through and characterise Australian coloniality in relation to the Pacific region.

34 McDonnell, 'Urban Land Grabbing by Political Elites'.

35 Stead, 'The Price of Fish'; Stead, Becoming Landowners; Bulloch, In Pursuit of Progress; Shrestha, 'Becoming a Development Category'. 
Contemporary horticultural labour is not a simple revamping of nineteenth-century blackbirding, but nor are these two disconnected phenomena; the Pacific labour trade forms part of the colonial lineage through which the Pacific and Australia are produced in relation to one another, and within which contemporary subjectivities, developmentalist paradigms and racialised inequalities are ultimately embedded, known and felt.

\section{Bibliography}

Altman, Jon. 'Modern Slavery in Remote Australia?'. Arena Magazine, no. 150 (Oct 2017): 12-15.

Bales, Kevin. Disposable People: New Slavery in the Global Economy. Los Angeles: University of California Press, 2012 (3rd ed.).

Banivanua Mar, Tracey. Decolonisation and the Pacific: Indigenous Globalisation and the Ends of Empire. Cambridge: Cambridge University Press, 2016.

—. Violence and Colonial Dialogue: The Australian-Pacific Indentured Labor Trade. Honolulu: University of Hawai'i Press, 2007.

Basok, Tanya. 'Free to Be Unfree: Mexican Guest Workers in Canada'. Labour, Capital and Society 32, no. 2 (1999): 191-21.

Bulloch, Hannah. In Pursuit of Progress: Narratives of Development on a Philippine Island. Honolulu: University of Hawai'i Press, 2017. doi.org/10.21313/ hawaii/9780824858865.001.0001.

Connell, John. 'From Blackbirds to Guestworkers in the South Pacific. Plus Ça Change...?'. The Economic and Labour Relations Review 20, no. 2 (2010): 111-22. doi.org/10.1177/103530461002000208.

Davidson, Julia O'Connell. 'Troubling Freedom: Migration, Debt, and Modern Slavery'. Migration Studies 1, no. 2 (2013): 176-95. doi.org/10.1093/ migration/mns002.

Doyle, Jesse and Manohar Sharma. 'Maximizing the Development Impacts from Temporary Migration: Recommendations for Australia’s Seasonal Worker Program'. Washington DC: World Bank Group, 2017.

Graves, Adrian. Cane and Labour: The Political Economy of the Queensland Sugar Industry, 1862-1906. Edinburgh: University of Edinburgh Press, 1993. 
'The Nature and Origins of Pacific Islands Labour Migration to Queensland, 1863-1906'. In International Labour Migration: Historical Perspectives, edited by Shula Marks and Peter Richardson, 112-39. London: Maurice Temple Smith, 1984.

Howes, Stephen. 'Satisfied Seasonal Workers'. DevPolicyBlog, 3 April 2018, www.devpolicy.org/satisfied-seasonal-workers-20180403/.

Joint Standing Committee on Foreign Affairs, Defence and Trade. Hidden in Plain Sight: An Inquiry into Establishing a Modern Slavery Act in Australia. Canberra: Parliament of the Commonwealth of Australia, 2017.

Lewis, Hannah, Peter Dwyer, Stuart Hogkinson and Louise Waite. 'HyperPrecarious Lives: Migrants, Work and Forced Labour in the Global North'. Progress in Human Geography 39, no. 5 (2015): 580-600. doi.org/10.1177/ 0309132514548303.

Locke, Sarina, Kallee Buchanan and Catherine Graue. 'Seasonal Worker Program in Australia Gets Backing from Farmers but with Concerns about Rogue Operators'. ABC News, 21 December 2017, www.abc.net.au/news/rural/ 2017-12-21/seasonal-worker-program-supported-by-farmers/9276672.

MacDermott, Therese and Brian Opeskin. 'Regulating Pacific Seasonal Labour in Australia'. Pacific Affairs 83, no. 2 (2010): 283-305. doi.org/10.5509/ 2010832283.

Maclellan, Nic and Peter Mares. 'Remittances and Labour Mobility in the Pacific: A Working Paper on Seasonal Work Programs in Australia for Pacific Islanders'. Working Paper, Institute for Social Research, Swinburne University of Technology, 2006.

Mares, Peter and Nic Maclellan. 'Pacific Seasonal Workers for Australian Horticulture: A Neat Fit?'. Asian and Pacific Migration Journal 16, no. 2 (2007): 271-88. doi.org/10.1177/011719680701600207.

McDonnell, Siobhan. 'Urban Land Grabbing by Political Elites: Exploring the Political Economy of Land and the Challenges of Regulation'. In Kastom, Property and Ideology, edited by Siobhan McDonnell, Matthew G. Allen and Colin Filer, 283-304. Canberra: ANU Press, 2017. doi.org/10.22459/ KPI.03.2017.09.

Miles, Robert. Capitalism and Unfree Labour: Anomaly or Necessity? London: Tavistock, 1987.

Moore, Clive. Kanaka: A History of Melanesian Mackay. Port Moresby: University of Papua New Guinea Press 1985. 
Moran, Anthony and Mark Mallman. 'Understanding Social Cohesion in Shepparton and Mildura: Literature Review’. Bundoora: La Trobe University and Victorian Multicultural Commission, 2015.

Mortensen, Reid. 'Slaving in Australian Courts: Blackbirding Cases, 1869-1871'. Journal of South Pacific Law 4 (2000), accessed 14 March 2019, www.usp. ac.ff/index.php?id=13200.

Munro, Doug. 'The Pacific Islands Labour Trade: Approaches, Methodologies, Debates'. Slavery and Abolition 14, no. 2 (1993): 87-108. doi.org/10.1080/ 01440399308575099.

. 'Revisionism and Its Enemies: Debating the Queensland Labour Trade'. The Journal of Pacific History 30, no. 2 (1995): 240-49. doi.org/10.1080/ 00223349508572798.

Quirk, Joel. 'The Anti-Slavery Project: Linking the Historical and Contemporary'. Human Rights Quarterly 28, no. 3 (2006): 565-98. doi.org/10.1353/hrq. 2006.0036.

Saunders, Kay. 'Masters and Servants'. Labour History 35 (1978): 96-111. doi.org/10.2307/27508338.

Scarr, Deryck. Fragments of Empire: A History of the Western Pacific High Commission, 1877-1914. Canberra: Australian National University Press, 1967.

- 'Recruits and Recruiters: A Portrait of the Pacific Islands Labour Trade'. The Journal of Pacific History 2, no. 1 (1967): 5-24. doi.org/10.1080/ 00223346708572099.

Shlomowitz, Ralph. 'Markets for Indentured and Time-Expired Melanesian Labour in Queensland, 1863-1906: An Economic Analysis'. The Journal of Pacific History 16, no. 2 (1981): 70-91. doi.org/10.1080/00223348108572416.

- 'Time-Expired Melanesian Labor in Queensland: An Investigation of Job Turnover, 1884-1906'. Pacific Studies 8, no. 2 (1985): 25-44.

Shrestha, Nanda. 'Becoming a Development Category'. In Power of Development, edited by Jonathan Crush, 266-77. London: Routledge, 1995.

Smith, Rachel E. 'Changing Standards of Living: The Paradoxes of Building a Good Life in Rural Vanuatu'. In The Quest for the Good Life in Precarious Times: Ethnographic Perspectives on the Domestic Moral Economy, edited by Chris Gregory and Jon Altman, 33-55. Canberra: ANU Press, 2018. doi.org/ 10.22459/QGLPT.03.2018.03. 
Stead, Victoria. Becoming Landowners: Entanglements of Custom and Modernity in Papua New Guinea and Timor-Leste. Honolulu: University of Hawai' $\mathrm{i}$ Press, 2017.

—. 'The Price of Fish: Problematising Discourses of Prosperity at the Pacific Marine Industrial Zone'. In Securing a Prosperous Future: Papers from the Second Annual Alfred Deakin Research Institute Papua New Guinea Symposium, 2012, edited by Jonathan Ritchie and Michelle Verso, 197-230. Goolwa: Crawford House Publishing, 2014.

Tinker, Hugh. A New System of Slavery: The Export of Indian Labour Overseas, 1830-1920. London: Oxford University Press, 1974.

Weitzer, Ronald. 'Human Trafficking and Contemporary Slavery'. Annual Review of Sociology 41 (2015): 223-42. doi.org/10.1146/annurev-soc-073014-112506.

Wolfe, Patrick. Traces of History: Elementary Structures of Race. London: Verso, 2016.

\section{Newspapers}

The Guardian

The Sydney Morning Herald

The Weekly Times 
This text is taken from Labour Lines and Colonial Power: Indigenous and Pacific Islander Labour Mobility in Australia, edited by Victoria Stead and Jon Altman, published 2019 by ANU Press, The Australian National University, Canberra, Australia.

doi.org/10.22459/LLCP.2019.06 